\title{
Synthesis and crystal structure of $\mathbf{N}, \mathbf{N}^{\prime}$-diallyl-N,N,N',N'- tetramethylethylenediammonium (dalltmen ${ }^{2+}$ ) compounds: $\{$ dalltmen $\}\left(\mathrm{ClO}_{4}\right)_{2}$ and the copper(I) nitrate $\pi$-complex $\left[\{\text { dalltmen }\}_{0.5} \mathrm{Cu}\left(\mathrm{NO}_{3}\right)_{2}\right]$
}

\author{
Mykhaylo MONCHAK ${ }^{1 *}$, Evgeny GORESHNIK $^{2}$, Maryan MYS'KIV $^{1}$ \\ ${ }^{1}$ Department of Inorganic Chemistry, Ivan Franko National University of Lviv, \\ Kyryla i Mefodiya St. 6, 79005 Lviv, Ukraine \\ ${ }^{2}$ Department of Inorganic Chemistry and Technology, Jožef Stefan Institute, \\ Jamova 39, SI-1000 Ljubljana, Slovenia \\ * Corresponding author. E-mail: mishamonchak@gmail.com
}

Received June 1, 2012; accepted June 27, 2012; available on-line November 5, 2012

$\mathbf{N}, \mathbf{N}^{\prime}$-diallyl-N,N,N',N'-tetramethylethylenediammonium dichloride (\{dalltmen $\left.\} \mathbf{C l}_{2}\right)$ was synthesized from $\mathbf{N}, \mathbf{N}, \mathbf{N}^{\prime}, \mathbf{N}^{\prime}$-tetramethylethylenediamine (obtained by the Eschweiler-Clarke reaction of ethylenediamine, formaldehyde and formic acid) and allyl chloride. Then an ethanol solution of KOH was added to replace the $\mathrm{Cl}^{-}$anions by $\mathrm{OH}^{-}$ones and $\mathbf{N}, \mathbf{N}^{\prime}$-diallyl-N,N,N', $\mathbf{N}^{\prime}$-tetramethylethylenediammonium dihydroxide $\left(\{\right.$ dalltmen $\left.\}(\mathrm{OH})_{2}\right)$ was obtained. Single crystals of $\{$ dalltmen $\}\left(\mathrm{ClO}_{4}\right)_{2}$ (I) and the $\pi$-complex $\left[\{\text { dalltmen }\}_{0.5} \mathrm{Cu}\left(\mathrm{NO}_{3}\right)_{2}\right]$ (II) were obtained from alcohol solutions containing the hydroxide of the

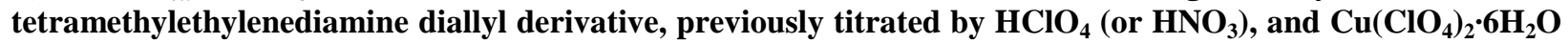
$\left(\right.$ or $\left.\mathrm{Cu}\left(\mathrm{NO}_{3}\right)_{2} \cdot 3 \mathrm{H}_{2} \mathrm{O}\right)$ by $a c$-electrochemical synthesis on copper wire electrodes. The structures of compounds I and II were determined by X-ray diffraction. Crystals I are orthorhombic: space group $P b c a, Z=4$, $a=11.4125(6), b=10.4604(5), c=15.2884(8) \AA, V=1825.1(2) \AA^{3}$. The structure consists of $N_{,} N^{\prime}$-diallyl$\mathrm{N}, \mathrm{N}, \mathrm{N}^{\prime}, \mathrm{N}^{\prime}$-tetramethylethylenediammonium cations and $\mathrm{ClO}_{4}^{-}$anions, which are held together by electrostatic interactions and hydrogen bonds. Crystals II are monoclinic: space group $P 2_{1} / c, Z=4$, $a=7.9620(4), b=8.2823(4), c=15.6224(8) \AA, \beta=96.793(2)^{\circ}, V=1022.97(9) \AA^{3}$. The structure contains infinite anionic chains $\left(\mathrm{Cu}\left(\mathrm{NO}_{3}\right)_{2}^{-}\right)_{n}$ with only one independent metal atom. The $\mathrm{C}=\mathrm{C}$ bonds of the centrosymmetric $\mathbf{N}, N^{\prime}$-diallyl-N,N,N',N'-tetramethylethylenediammonium cation are $\pi$-coordinated by $\mathrm{Cu}(\mathrm{I})$ atoms from parallel inorganic fragments, so that the dalltmen ${ }^{2+}$ moities play a bridging role, connecting separate $\left(\mathrm{Cu}\left(\mathrm{NO}_{3}\right)_{2}^{-}\right)_{\mathrm{n}}$ polymeric chains into layers (coordination nets). A branched system of hydrogen bonds connects the nets into a framework.

N,N'-diallyl-N,N,N',N'-tetramethylethylenediammonium cation / Anionic chains / Copper(I) nitrate $\pi$-complex / Hydrogen bonds

\section{Introduction}

Organic ligands playing a bridging role are useful in the synthesis of metal compounds with polymeric one-, two- or three-dimensional coordination networks [1]. N-allyl derivatives of ethylenediamine are convenient "materials" for such purposes: variation of the number of allyl groups is the key to obtain a series of polydentatic $\pi$-ligands. The similarity of the latter gives an opportunity for structural comparison and observation of crystal engineering regularities. Earlier structural investigations of copper(I) halide $\pi$-complexes with the derivatives $[2,3]$, including $\mathbf{N}, \mathrm{N}^{\prime}$-diallyl-N,N,N',N'tetramethylethylenediammonium $[4,5], \quad$ revealed structural diversity on one side and similarities on the other. To continue the research, we undertook the synthesis of new copper(I) ionic compounds; the results of this investigation are presented below.

Experimental section

Synthesis of $N, N^{\prime}$-diallyl- $N, N, N^{\prime}, N^{\prime}-$ tetramethylethylenediammonium dihydroxide $\left(\left\{\right.\right.$ dalltmen\} $\left.(\mathrm{OH})_{2},\left[\mathrm{C}_{2} \mathrm{H}_{4} \mathrm{~N}_{2}\left(\mathrm{CH}_{3}\right)_{4}\left(\mathrm{C}_{3} \mathrm{H}_{5}\right)_{2}\right](\mathrm{OH})_{2}\right)$

The synthesis of N,N'-diallyl-N,N,N',N'tetramethylethylenediammonium dihydroxide was performed in several steps. 
Preparation of $\mathrm{N}, \mathrm{N}, \mathrm{N}^{\prime}, \mathrm{N}^{\prime}$-tetramethylethylenediamine was carried out by reaction of ethylenediamine with formaldehyde and formic acid according to the Eschweiler-Clarke procedure (by the general method of obtaining tertiary amines from primary or secondary ones) [6].

$$
\begin{aligned}
& \mathrm{H}_{2} \mathrm{NC}_{2} \mathrm{H}_{4} \mathrm{NH}_{2}+4 \mathrm{CH}_{2} \mathrm{O}+4 \mathrm{HCOOH} \stackrel{t^{\circ}}{\longrightarrow} \\
& \left(\mathrm{CH}_{3}\right)_{2} \mathrm{NC}_{2} \mathrm{H}_{4} \mathrm{~N}\left(\mathrm{CH}_{3}\right)_{2}+4 \mathrm{CO}_{2}+4 \mathrm{H}_{2} \mathrm{O} .
\end{aligned}
$$

Formaldehyde (35\% solution, $38 \mathrm{ml})$ and $90 \%$ formic acid $(52 \mathrm{ml})$ were added to ethylenediamine $(6.65 \mathrm{ml}, 6.0 \mathrm{~g})$. The reaction mixture was refluxed in a water bath. When the vigorous evolution of $\mathrm{CO}_{2}$ had finished, the heating was continued for six hours (the total time of the synthesis was $\sim 11 \mathrm{~h}$ ). Then an excess of $36 \% \mathrm{HCl}(22 \mathrm{ml})$ was added; unreacted formaldehyde and formic acid were removed by distillation. N,N,N',N'-tetramethylethylenediamine was liberated from its hydrochloride by adding an excess of concentrated aqueous $\mathrm{KOH}$ to the residue and extracting with benzene. The solvent and other volatile impurities were removed to give a virtually pure product with a yield of $\sim 80 \%$, which then was distilled under reduced pressure $\left(40 \mathrm{mmHg} / 80^{\circ} \mathrm{C}\right)$.

$\mathrm{N}, \mathrm{N}$-diallyl-N,N,N',N'-tetramethylethylenediammonium dichloride was synthesized in the following way: allyl chloride $(17 \mathrm{~g}, 18 \mathrm{ml}, 0.22 \mathrm{~mol}$, small excess) was added dropwise to $11.6 \mathrm{~g}(0.1 \mathrm{~mol})$ of $\mathrm{N}, \mathrm{N}, \mathrm{N}^{\prime}, \mathrm{N}^{-}$-tetramethylethylenediamine in benzene.
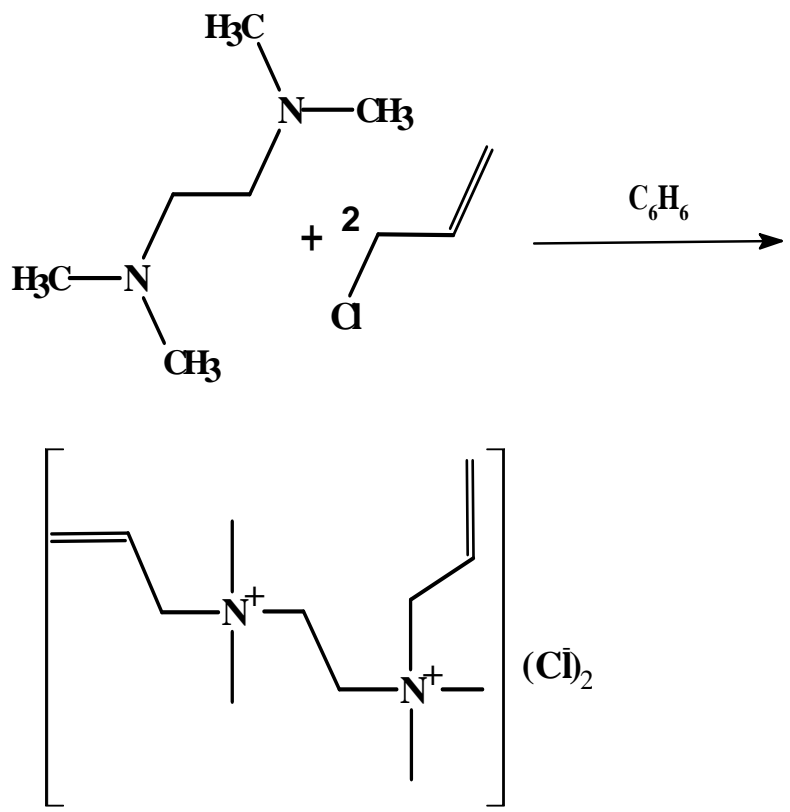

The mixture was refluxed in a water bath for $20 \mathrm{~h}$. The product, in the form of a white precipitate, was filtered off. The yield was $\sim 40 \%$.
Potassium hydroxide (in $\mathrm{C}_{2} \mathrm{H}_{5} \mathrm{OH}$ ) was added to an alcohol solution of $\mathrm{N}, \mathrm{N}^{\prime}$-diallyl-N,N,N',N'-tetramethylethylenediammonium dichloride:

$$
\begin{aligned}
& {\left[\mathrm{C}_{2} \mathrm{H}_{4} \mathrm{~N}_{2}\left(\mathrm{CH}_{3}\right)_{4}\left(\mathrm{C}_{3} \mathrm{H}_{5}\right)_{2}\right] \mathrm{Cl}_{2}+2 \mathrm{KOH} \stackrel{\text { ethanol }}{\longrightarrow}} \\
& {\left[\mathrm{C}_{2} \mathrm{H}_{4} \mathrm{~N}_{2}\left(\mathrm{CH}_{3}\right)_{4}\left(\mathrm{C}_{3} \mathrm{H}_{5}\right)_{2}\right](\mathrm{OH})_{2}+2 \mathrm{KCl} \downarrow+2 \mathrm{H}_{2} \mathrm{O} .}
\end{aligned}
$$

$\mathrm{KCl}$ was filtered off and the ethanol solution of the resulting $\mathrm{N}, \mathrm{N}$ '-diallyl-N,N,N',N'-tetramethylethylenediammonium dihydroxide was used in further syntheses.

\section{Preparation of $\{$ dalltmen $\}\left(\mathrm{ClO}_{4}\right)_{2}(\mathrm{I})$}

Colourless crystals of compound I were obtained on the copper wires of a reactor containing an ethanol solution of $0.25 \mathrm{~g} \quad(\sim 0.001 \mathrm{~mol}) \quad$ of $\left[\mathrm{C}_{2} \mathrm{H}_{4} \mathrm{~N}_{2}\left(\mathrm{CH}_{3}\right)_{4}\left(\mathrm{C}_{3} \mathrm{H}_{5}\right)_{2}\right](\mathrm{OH})_{2}$, previously titrated by $52 \% \mathrm{HClO}_{4}$ to $\mathrm{pH} \sim 4$, in presence of $0.40 \mathrm{~g}$ $(\sim 0.001 \mathrm{~mol})$ of $\mathrm{Cu}\left(\mathrm{ClO}_{4}\right)_{2} \cdot 6 \mathrm{H}_{2} \mathrm{O}$. The crystals were formed after ten days (last three days in a refrigerator at $\left.-1^{\circ} \mathrm{C}\right)$.

\section{Preparation of $\left[\{\text { dalltmen }\}_{0.5} \mathrm{Cu}\left(\mathrm{NO}_{3}\right)_{2}\right]$ (II)}

Colourless crystals of complex II were obtained by the $a c$-electrochemical technique [7] on copper wire electrodes from an alcohol solution of $0.5 \mathrm{~g}$ $(\sim 0.002 \mathrm{~mol})$ of $\mathrm{Cu}\left(\mathrm{NO}_{3}\right)_{2} \cdot 3 \mathrm{H}_{2} \mathrm{O}$ and $0.25 \mathrm{~g}$ $(\sim 0.001 \mathrm{~mol})$ of $\quad\left[\mathrm{C}_{2} \mathrm{H}_{4} \mathrm{~N}_{2}\left(\mathrm{CH}_{3}\right)_{4}\left(\mathrm{C}_{3} \mathrm{H}_{5}\right)_{2}\right](\mathrm{OH})_{2}$, previously titrated by $56 \% \mathrm{HNO}_{3}$ to $\mathrm{pH}=3.5-4$, after five days.

\section{X-ray crystal structure determination}

Single crystals of I and II, previously studied by the photographic method, were investigated using a Rigaku AFC7R single crystal diffractometer (CCD detector, Mo $K \alpha$ radiation, graphite monochromator and $\omega$-scanning) equipped with a low-temperature device. The intensities were corrected for Lorentz and polarization factors. The diffraction data were processed with the Rigaku CrystalClear software [8]. The structures were solved by direct methods; the light atoms were found by Fourier difference syntheses. An analytical absorption correction was applied [9]. The structures were solved using SIR-92 [10] and refined with SHELX [11]. All the hydrogen atoms in the compounds were located based on geometrical considerations.

Selected crystallographic parameters and a summary of the data collections for compounds I and II are given in Table 1. Atomic positional and displacement parameters for I and II are given in Tables 2 and 3.

The figures were prepared using DIAMOND v3.1 software [12]. 
M. Monchak et al., Synthesis and crystal structure of N,N'-diallyl-N,N,N',N'-tetramethylethylenediammonium ...

Table 1 Crystallographic characteristics and summary of the structure determinations for I and II.

\begin{tabular}{|c|c|c|}
\hline Parameter & I & II \\
\hline Empirical formula & $\mathrm{C}_{12} \mathrm{H}_{26} \mathrm{~N}_{2} \cdot 2\left(\mathrm{ClO}_{4}\right)$ & $\mathrm{C}_{6} \mathrm{H}_{13} \mathrm{~N}_{3} \mathrm{O}_{6} \mathrm{Cu}$ \\
\hline Formula weight & 397.25 & 286.73 \\
\hline Temperature, $\mathrm{K}$ & 200 & 200 \\
\hline Wavelength, $\AA$ & $0.71069(\mathrm{Mo} K \alpha)$ & $0.71069($ Mo $K \alpha)$ \\
\hline Crystal system, space group & Orthorhombic, $\mathrm{Pbca}$ & Monoclinic, $P 2_{1} / \mathrm{c}$ \\
\hline Unit cell dimensions & & \\
\hline$a, \AA$ & $11.4125(6)$ & $7.9620(4)$ \\
\hline$b, \AA$ & $10.4604(5)$ & $8.2823(4)$ \\
\hline$c, \AA$ & $15.2884(8)$ & $15.6224(8)$ \\
\hline$\beta,^{\circ}$ & - & $96.793(2)$ \\
\hline Volume, $\AA^{3}$ & $1825.12(16)$ & $1022.97(9)$ \\
\hline$Z$ & 4 & 4 \\
\hline Calculated density & 1.446 & 1.862 \\
\hline Absorption coefficient, $\mathrm{mm}^{-1}$ & 0.40 & 2.16 \\
\hline$F(000)$ & 840 & 588 \\
\hline Crystal size, $\mathrm{mm}$ & $0.12 \times 0.1 \times 0.1$ & $0.28 \times 0.2 \times 0.08$ \\
\hline Shape, colour & chunk, colorless & plate, colorless \\
\hline$\theta$ range for data collection, deg & from 3.0 to 29.0 & from 2.6 to 29.1 \\
\hline Limiting indices & $-14<h<15$ & $-10<h<6$ \\
\hline & $-8<k<14$ & $-10<k<11$ \\
\hline & $-12<l<20$ & $-12<l<20$ \\
\hline Refinement method & full-matrix least-squares on $F^{2}$ & full-matrix least-squares on $F^{2}$ \\
\hline Measured reflections & 7225 & 4240 \\
\hline Independent reflections & 2241 & 2303 \\
\hline Reflections with $F>4 \sigma(F)$ & 1836 & 1876 \\
\hline Free parameters & 110 & 146 \\
\hline Weighting scheme* & $1 /\left[\sigma^{2}\left(F_{\mathrm{o}}^{2}\right)+(0.1702 \mathrm{P})^{2}+1.1071 \mathrm{P}\right]$ & $1 /\left[\sigma^{2}\left(F_{\mathrm{o}}^{2}\right)+(0.088 \mathrm{P})^{2}+2.2316 \mathrm{P}\right]$ \\
\hline Goodness-of-fit on $F^{2}$ & 1.12 & 1.11 \\
\hline Final R indices $[I>2 \sigma(I)]$ & $\mathrm{R}=0.088, \mathrm{wR}=0.26$ & $\mathrm{R}=0.059, \mathrm{wR}=0.16$ \\
\hline $\mathrm{R}$ indices (all data) & $\mathrm{R}=0.099, \mathrm{wR}=0.28$ & $\mathrm{R}=0.070, \mathrm{wR}=0.17$ \\
\hline Largest peaks and holes, e $\AA^{-3}$ & $1.29,-0.83$ & $1.02,-0.90$ \\
\hline
\end{tabular}

$* \mathrm{P}=\left(F_{\mathrm{o}}^{2}+2 F_{\mathrm{c}}^{2}\right) / 3$

\section{Results and discussion}

The structure of the organic salt N,N'diallyl-N,N,N',N'-tetramethylethylenediammonium perchlorate (I) consists of centrosymmetric dalltmen ${ }^{2+}$ cations and $\mathrm{ClO}_{4}^{-}$anions (Fig. 1). The length of the $\mathrm{C}=\mathrm{C}$ bond is equal to $1.302(4) \AA$, the angle $\mathrm{C}(2)-\mathrm{C}(3)=\mathrm{C}(4)$ is equal to $122.9(2)^{\circ}$ (Table 4$)$. The electrostatic interaction between the ions is supplemented by H-bonds. Hydrogen atoms of the methyl and allyl groups form (C)H...O contacts (2.48-2.70 $\AA$ ), which fix the organic moieties in the crystal and prevent disorder.

The structure of II contains one independent copper(I) atom with a trigonal-pyramidal coordination environment formed by the $\mathrm{C}=\mathrm{C}$-bond of an allyl group of centrosymmetric dalltmen ${ }^{2+}$, two oxygen atoms of bridging $\mathrm{NO}_{3}{ }^{-}$anions and one oxygen atom from a monodentate nitrate anion (Fig. 2). The apical position is occupied by an $\mathrm{O}$ atom. The $\pi$-interaction $\mathrm{Cu}-(\mathrm{C}=\mathrm{C})$ is characterized by notable strength. The displacement of the copper(I) atom from the equatorial plane is only $\sim 0.08 \AA$. The length of the coordinated $\mathrm{C}=\mathrm{C}$ bond is $1.386(5) \AA$; the distance from the metal atom to the middle of the double bond is 1.893(2) $\AA$; the contact $\mathrm{Cu}-\mathrm{O}(3)$ is $2.549(3) \AA$, i.e. relatively long compared to the other two $\mathrm{Cu}-\mathrm{O}$ distances (1.975(2) and 2.029(2) $\AA$ ) (Table 4). A comparison of the interatomic distances shows an elongation for the $\mathrm{N}-\mathrm{O}$ bonds with $\mathrm{O}$ atoms that are coordinated by copper(I) (1.280(3) $\AA$ for $\mathrm{N}(2)-\mathrm{O}(1)$ and 1.249(4) $\AA$ for $\mathrm{N}(2)-\mathrm{O}(3)$, in contrast with 1.229(3) $\AA$ for $\mathrm{N}(2)-\mathrm{O}(2))$. Weakening of the bond $\mathrm{N}(3)-\mathrm{O}(5)$ is caused by the formation of the hydrogen contact $\mathrm{C}(2) \mathrm{H}(21) \ldots \mathrm{O}(5)$.

Helical infinite $\left(\mathrm{Cu}\left(\mathrm{NO}_{3}\right)_{2}\right)_{\mathrm{n}}{ }^{\mathrm{n}-}$ chains are formed in the structure of II. The nitrate anion in this compound plays a bridging role, similarly to the halide anions in the structures of the previously studied complexes of copper(I) with $\mathrm{N}$-allyl derivatives of ethylenediamine $[2,4]$. A polymeric $\left(\mathrm{Cu}\left(\mathrm{NO}_{3}\right)_{2}\right)_{\mathrm{n}}{ }^{\mathrm{n}-}$ chain is formed by assembling $\mathrm{Cu}$-centered trigonal pyramids through 
$\mathrm{O}$ atoms of $\mathrm{NO}_{3}^{-}$anions. The copper(I) atoms are separated from each other by $4.50 \AA$. Formation of polymeric cuprous nitrate fragments in $\mathrm{Cu}(\mathrm{I})$ $\pi$-complexes is rare. In the majority of known $\mathrm{Cu}(\mathrm{I})$ $\pi$-compounds, the $\mathrm{NO}_{3}{ }^{-}$anion is located in an outer coordination sphere [13], or the structures contain islet copper(I) nitrate units [14,15]. The crystal structures of only a few copper(I) $\pi$-complexes with infinite cuprous nitrate fragments are described in the literature. One of them, the compound $\left[\mathrm{Cu}\left(\mathrm{C}_{3} \mathrm{H}_{5} \mathrm{CN}\right)\left(\mathrm{NO}_{3}\right)\right]$, has a zigzag-shaped chain $\left(\mathrm{Cu}\left(\mathrm{NO}_{3}\right)_{2}\right)_{\mathrm{n}} \quad[16]$. In the structure of another $\pi$-complex, $\left[\left\{\left(\mathrm{C}_{3} \mathrm{H}_{5}\right) \mathrm{NHC}\left(\mathrm{NH}_{2}\right)_{2}\right\} \mathrm{Cu}\left(\mathrm{NO}_{3}\right)_{2}\right]$, a similar helical anion $\left(\mathrm{Cu}\left(\mathrm{NO}_{3}\right)_{2}\right)_{\mathrm{n}}{ }^{\mathrm{n}-}$ is formed, but it has more twisted shape [17]. The dalltmen ${ }^{2+}$ cations in II display a bridging role, connecting separate anionic chains into two-dimensional layers
(Fig. 3). Such coordination behavior is typical for this organic ligand [4,5] and is similar to the behavior of other N-allyl derivatives of ethylenediamine in the structures of cuprous halide $\pi$-complexes.

As it is usually for coordination compounds, weak interactions are significant for the structure organization [18]. As mentioned above, in I they play a role in the structure ordering, making the interaction between dalltmen ${ }^{2+}$ cations and $\mathrm{ClO}_{4}^{-}$anions more directional. In the structure of II hydrogen bonds connect the coordination nets $\left\{\mathrm{Cu}\left(\mathrm{NO}_{3}\right)_{2}-(\right.$ dalltmen $)-$ $\left.\mathrm{Cu}\left(\mathrm{NO}_{3}\right)_{2}\right\}_{\mathrm{m}}$ into a framework (Table 5). In the case of branched ligands, such as $\mathrm{N}, \mathrm{N}^{\prime}$-diallyl-N,N,N',N'tetramethylethylenediammonium, the role of the hydrogen bonds, which fix the distinct parts of the structure, increases significantly.

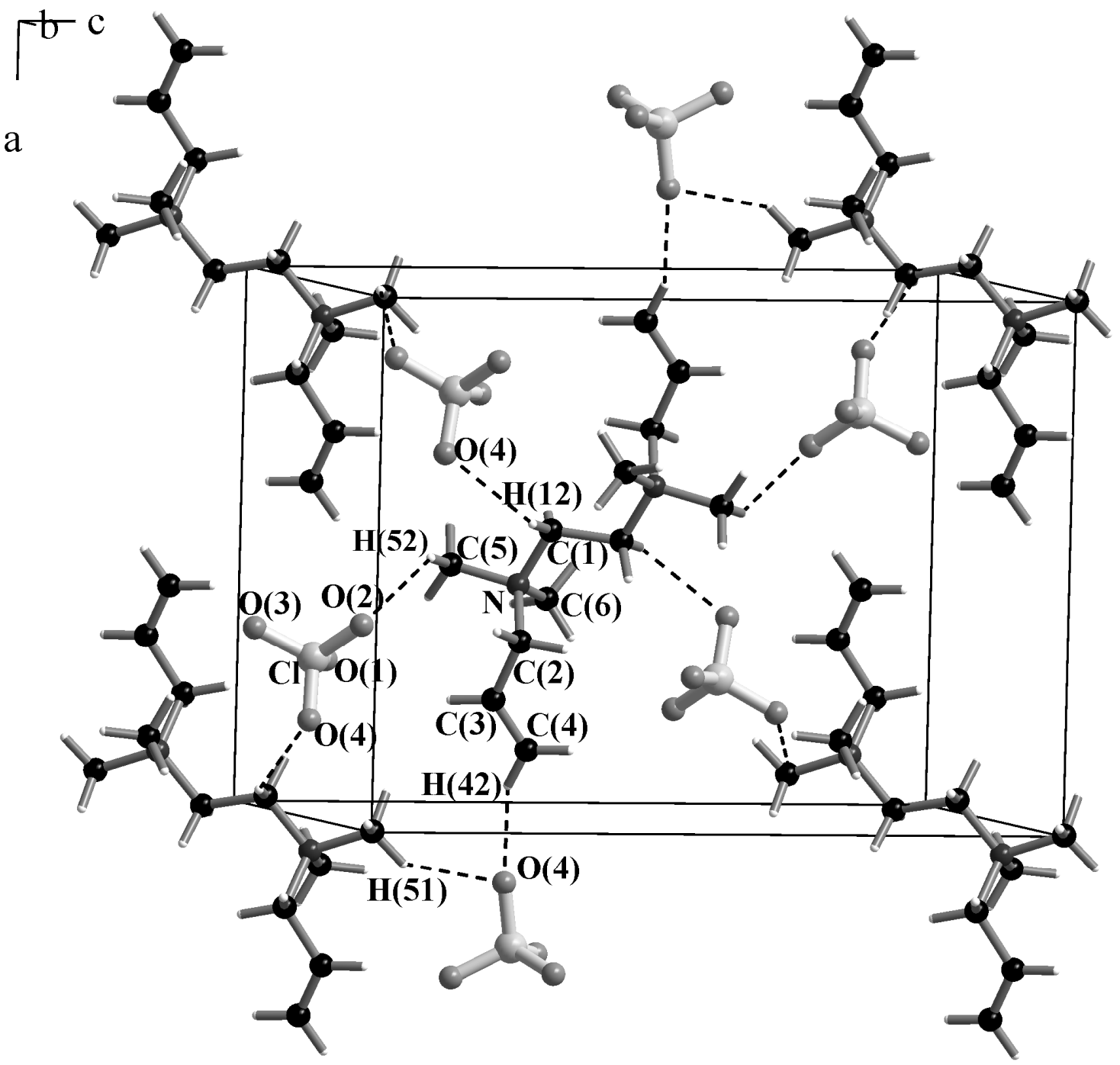

Fig. 1 Fragment of the crystal structure of $\mathbf{I}$. 
M. Monchak et al., Synthesis and crystal structure of N,N'-diallyl-N,N,N',N'-tetramethylethylenediammonium ...

Table 2 Fractional atomic coordinates and isotropic/equivalent isotropic displacement parameters $\left(\AA^{2}\right)$ for $\mathbf{I}$.

\begin{tabular}{|c|c|c|c|c|}
\hline Atom & $x$ & $y$ & $z$ & $U_{\mathrm{iso}} / U_{\mathrm{eq}}{ }^{\mathrm{a}}, \AA^{2}$ \\
\hline $\mathrm{Cl}(1)$ & $0.75531(4)$ & $0.21339(5)$ & $0.65202(3)$ & $0.04086(16)$ \\
\hline $\mathrm{O}(1)$ & $0.76023(17)$ & $0.0777(2)$ & $0.64324(13)$ & $0.0588(5)$ \\
\hline $\mathrm{O}(2)$ & $0.8154(2)$ & $0.2544(2)$ & $0.72945(13)$ & $0.0748(6)$ \\
\hline $\mathrm{O}(3)$ & $0.8086(2)$ & $0.2705(2)$ & $0.57815(14)$ & $0.0782(7)$ \\
\hline $\mathrm{O}(4)$ & $0.63712(18)$ & $0.2516(2)$ & $0.65621(18)$ & $0.0898(8)$ \\
\hline $\mathrm{N}(1)$ & $0.40957(14)$ & $-0.03727(15)$ & $0.60420(10)$ & $0.0352(4)$ \\
\hline $\mathrm{C}(1)$ & $0.50848(17)$ & $0.0133(2)$ & $0.54831(13)$ & $0.0402(5)$ \\
\hline $\mathrm{H}(11)$ & 0.581 & -0.025 & 0.567 & 0.048 \\
\hline $\mathrm{H}(12)$ & 0.515 & 0.104 & 0.557 & 0.048 \\
\hline $\mathrm{C}(2)$ & $0.29862(19)$ & $0.0371(2)$ & $0.58438(16)$ & $0.0488(6)$ \\
\hline $\mathrm{H}(21)$ & 0.311 & 0.125 & 0.600 & 0.059 \\
\hline $\mathrm{H}(22)$ & 0.284 & 0.033 & 0.521 & 0.059 \\
\hline $\mathrm{C}(3)$ & $0.19224(19)$ & $-0.0098(3)$ & $0.63053(17)$ & $0.0516(6)$ \\
\hline $\mathrm{H}(31)$ & 0.190 & -0.007 & 0.691 & 0.062 \\
\hline $\mathrm{C}(4)$ & $0.1012(2)$ & $-0.0551(3)$ & $0.58961(19)$ & $0.0690(8)$ \\
\hline $\mathrm{H}(41)$ & 0.100 & -0.059 & 0.528 & 0.083 \\
\hline $\mathrm{H}(42)$ & 0.036 & -0.083 & 0.621 & 0.083 \\
\hline $\mathrm{C}(5)$ & $0.4453(2)$ & $-0.0162(2)$ & $0.69791(13)$ & $0.0471(5)$ \\
\hline $\mathrm{H}(51)$ & 0.387 & -0.052 & 0.736 & 0.071 \\
\hline $\mathrm{H}(52)$ & 0.452 & 0.073 & 0.709 & 0.071 \\
\hline $\mathrm{H}(53)$ & 0.519 & -0.056 & 0.708 & 0.071 \\
\hline $\mathrm{C}(6)$ & $0.3915(2)$ & $-0.1775(2)$ & $0.59060(15)$ & $0.0449(5)$ \\
\hline $\mathrm{H}(61)$ & 0.384 & -0.219 & 0.646 & 0.067 \\
\hline $\mathrm{H}(62)$ & 0.457 & -0.212 & 0.559 & 0.067 \\
\hline $\mathrm{H}(63)$ & 0.321 & -0.191 & 0.557 & 0.067 \\
\hline
\end{tabular}

${ }^{\mathrm{a}}$ For non-hydrogen atoms $U_{\mathrm{eq}}$ is defined as one-third of the trace of the orthogonalized $U_{i j}$ tensor $\mathrm{U}_{\mathrm{eq}}=1 / 3 \sum_{i} \sum_{j} U_{i j} a_{i}^{*} a_{j}^{*}\left(\vec{a}_{i} \vec{a}_{j}\right)$, for hydrogen $-U_{\text {iso. }}$.

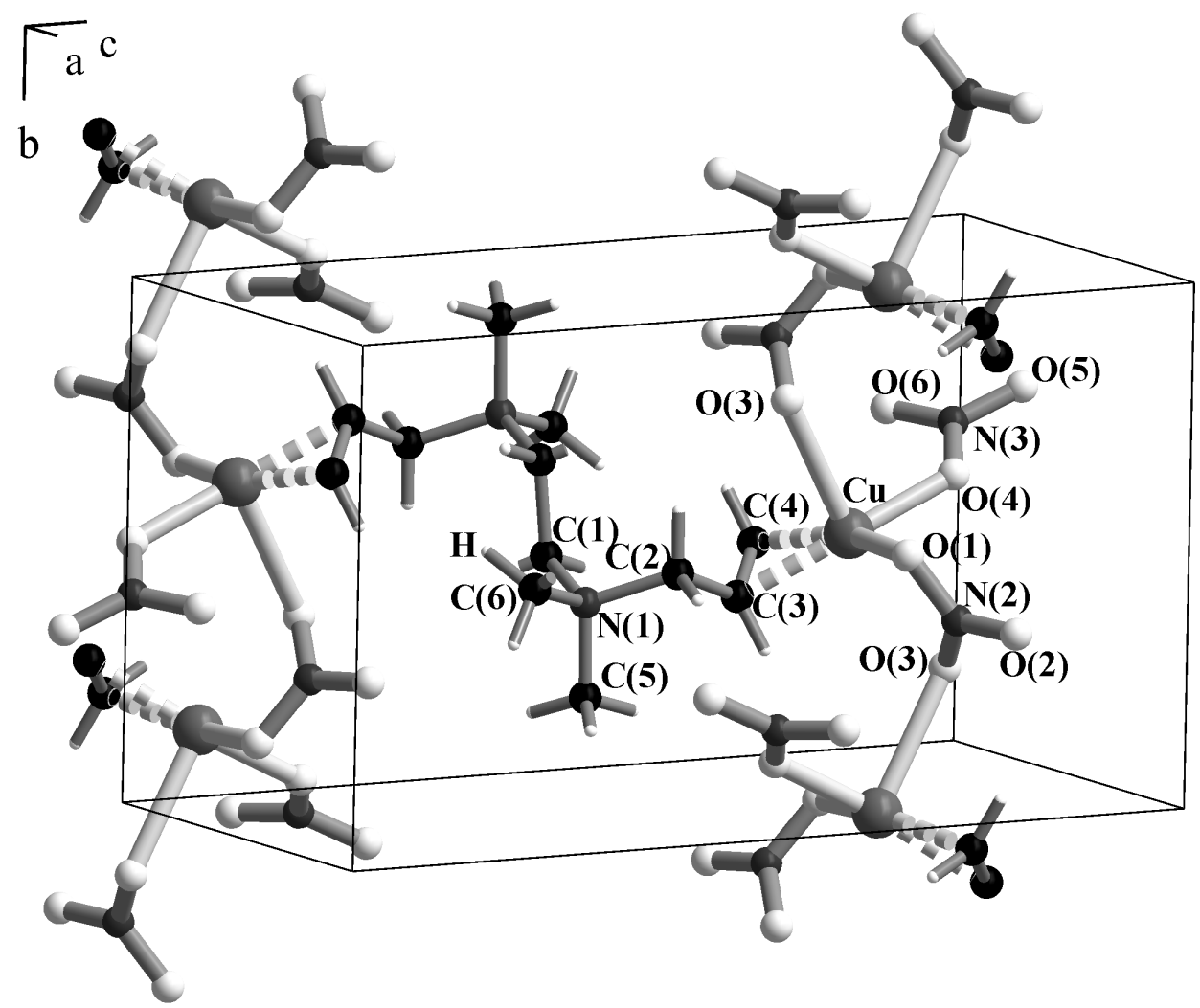

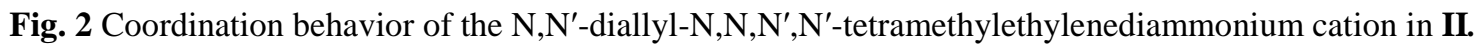


Table 3 Fractional atomic coordinates and isotropic/equivalent isotropic displacement parameters $\left(\AA^{2}\right)$ for II.

\begin{tabular}{|c|c|c|c|c|}
\hline Atom & $x$ & $y$ & $z$ & $U_{\mathrm{iso}} / U_{\mathrm{eq}}{ }^{\mathrm{a}}, \AA^{2}$ \\
\hline $\mathrm{Cu}$ & $0.39261(5)$ & $-0.02858(5)$ & $1.25955(2)$ & $0.03092(11)$ \\
\hline $\mathrm{O}(1)$ & $0.6474(3)$ & $-0.0370(3)$ & $1.25994(16)$ & $0.0324(5)$ \\
\hline $\mathrm{O}(2)$ & $0.8498(3)$ & $-0.1684(3)$ & $1.33559(17)$ & $0.0421(6)$ \\
\hline $\mathrm{O}(3)$ & $0.5946(3)$ & $-0.2628(3)$ & $1.32169(16)$ & $0.0365(6)$ \\
\hline $\mathrm{O}(4)$ & $0.4301(3)$ & $0.0766(3)$ & $1.37368(15)$ & $0.0404(6)$ \\
\hline $\mathrm{O}(5)$ & $0.3482(3)$ & $0.2200(3)$ & $1.47675(15)$ & $0.0408(6)$ \\
\hline $\mathrm{O}(6)$ & $0.1743(3)$ & $0.1704(4)$ & $1.36275(19)$ & $0.0565(8)$ \\
\hline $\mathrm{N}(1)$ & $0.1808(3)$ & $-0.1568(3)$ & $1.00286(16)$ & $0.0255(5)$ \\
\hline $\mathrm{N}(2)$ & $0.7000(3)$ & $-0.1584(3)$ & $1.30626(16)$ & $0.0292(6)$ \\
\hline $\mathrm{N}(3)$ & $0.3138(3)$ & $0.1576(3)$ & $1.40433(17)$ & $0.0296(6)$ \\
\hline $\mathrm{C}(1)$ & $0.0044(3)$ & $-0.0920(3)$ & $1.00382(18)$ & $0.0242(6)$ \\
\hline $\mathrm{H}(11)$ & -0.037 & -0.124 & 1.057 & 0.029 \\
\hline $\mathrm{H}(12)$ & -0.068 & -0.139 & 0.956 & 0.029 \\
\hline $\mathrm{C}(2)$ & $0.3028(4)$ & $-0.0945(4)$ & $1.07933(19)$ & $0.0267(6)$ \\
\hline $\mathrm{H}(21)$ & 0.416 & -0.129 & 1.072 & 0.032 \\
\hline $\mathrm{H}(22)$ & 0.301 & 0.022 & 1.079 & 0.032 \\
\hline $\mathrm{C}(3)$ & $0.2577(4)$ & $-0.1539(4)$ & $1.1641(2)$ & $0.0298(7)$ \\
\hline $\mathrm{H}(31)$ & 0.304 & -0.251 & 1.185 & 0.036 \\
\hline $\mathrm{C}(4)$ & $0.1505(4)$ & $-0.0718(4)$ & $1.2126(2)$ & $0.0343(7)$ \\
\hline $\mathrm{H}(41)$ & 0.102 & 0.025 & 1.192 & 0.041 \\
\hline $\mathrm{H}(42)$ & 0.126 & -0.114 & 1.265 & 0.041 \\
\hline $\mathrm{C}(5)$ & $0.1698(4)$ & $-0.3380(4)$ & $1.0079(2)$ & $0.0346(8)$ \\
\hline $\mathrm{H}(51)$ & 0.164 & -0.369 & 1.066 & 0.052 \\
\hline $\mathrm{H}(52)$ & 0.268 & -0.385 & 0.987 & 0.052 \\
\hline $\mathrm{H}(53)$ & 0.070 & -0.374 & 0.972 & 0.052 \\
\hline $\mathrm{C}(6)$ & $0.2518(4)$ & $-0.1128(4)$ & $0.9217(2)$ & $0.0349(7)$ \\
\hline $\mathrm{H}(61)$ & 0.354 & -0.052 & 0.935 & 0.052 \\
\hline $\mathrm{H}(62)$ & 0.171 & -0.048 & 0.886 & 0.052 \\
\hline $\mathrm{H}(63)$ & 0.275 & -0.209 & 0.891 & 0.052 \\
\hline
\end{tabular}

${ }^{\mathrm{a}}$ For non-hydrogen atoms $U_{\text {eq }}$ is defined as one-third of the trace of the orthogonalized $U_{i j}$ tensor $\mathrm{U}_{\mathrm{eq}}=1 / 3 \sum_{i} \sum_{j} U_{i j} a_{i}^{*} a_{j}^{*}\left(\vec{a}_{i} \vec{a}_{j}\right)$, for hydrogen $-U_{\text {iso }}$.

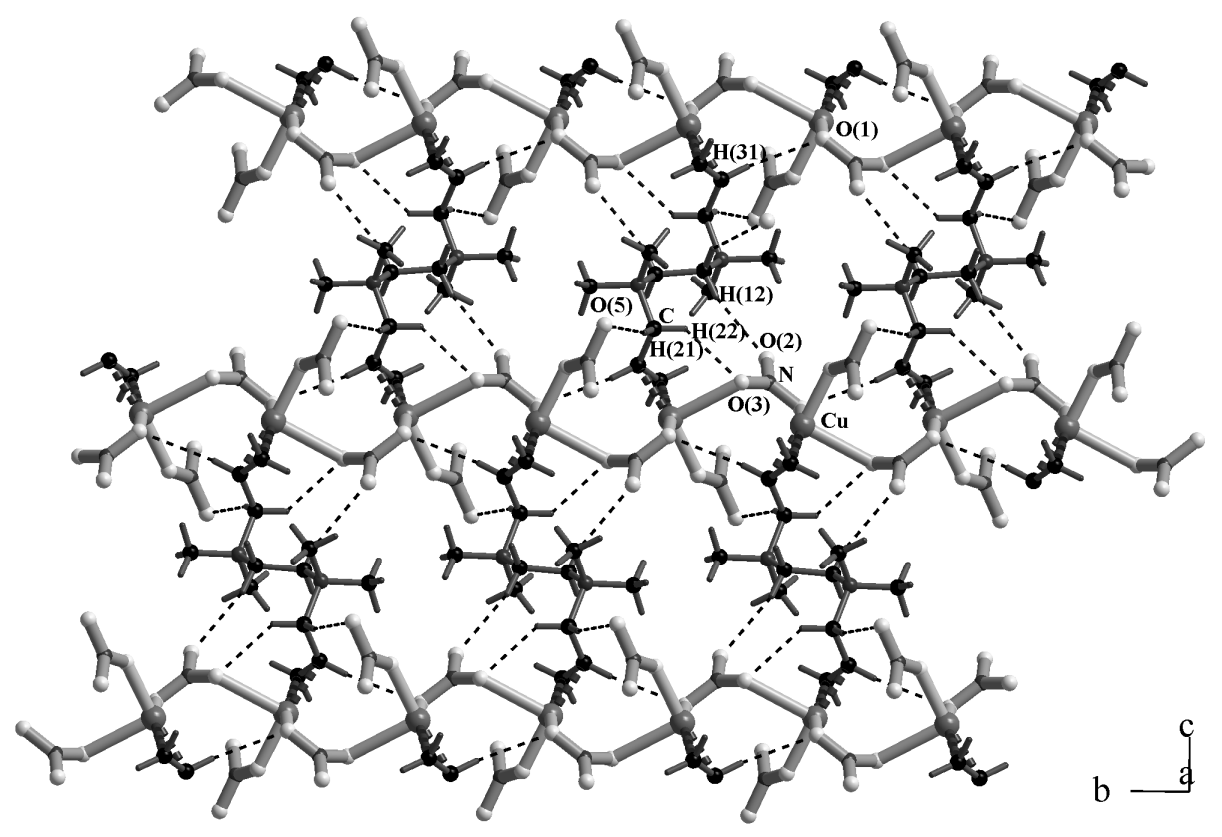

Fig. 3 Fragment of the coordination net in the crystal structure of II. 
M. Monchak et al., Synthesis and crystal structure of N,N'-diallyl-N,N,N',N'-tetramethylethylenediammonium ...

Table 4 Selected bond lengths and angles in the structures of I and II.

\begin{tabular}{l|c|c|c|c}
\hline & Bond & $d, \AA$ & Angle & $\omega$, deg \\
\hline I & $\mathrm{N}-\mathrm{C}(6)$ & $1.496(3)$ & $\mathrm{C}(6) \mathrm{NC}(2)$ & $111.1(2)$ \\
& $\mathrm{N}-\mathrm{C}(5)$ & $1.506(3)$ & $\mathrm{C}(5) \mathrm{NC}(2)$ & $110.0(2)$ \\
& $\mathrm{N}-\mathrm{C}(1)$ & $1.511(2)$ & $\mathrm{C}(1) \mathrm{NC}(2)$ & $109.3(2)$ \\
& $\mathrm{N}-\mathrm{C}(2)$ & $1.517(3)$ & $\mathrm{NC}(1) \mathrm{C}(1)^{\mathrm{i}}$ & $113.0(2)$ \\
& $\mathrm{C}(1)-\mathrm{C}(1)^{i a}$ & $1.516(4)$ & $\mathrm{C}(2) \mathrm{C}(3) \mathrm{C}(4)$ & $122.7(2)$ \\
& $\mathrm{C}(2)-\mathrm{C}(3)$ & $1.488(3)$ & $\mathrm{C}(4) \mathrm{CuC}(3)$ & $40.2(1)$ \\
& $\mathrm{C}(3)=\mathrm{C}(4)$ & $1.302(4)$ & $\mathrm{O}(1) \mathrm{CuO}(4)$ & $88.2(1)$ \\
& $\mathrm{Cu}-\mathrm{O}(1)$ & $2.029(2)$ & $\mathrm{O}(1) \mathrm{CuO}(3)$ & $93.1(4)$ \\
& $\mathrm{Cu}-\mathrm{O}(3)$ & $1.549(3)$ & $\mathrm{O}(3) \mathrm{CuO}(4)$ & $116.3(2)$ \\
& $\mathrm{Cu}-\mathrm{O}(4)$ & $1.975(2)$ & $\mathrm{C}(3) \mathrm{CuO}(1)$ & $115.4(2)$ \\
& $\mathrm{Cu}-m$ & $\mathrm{C}(2) \mathrm{C}(3) \mathrm{C}(4)$ & $123.5(3)$ \\
& $\mathrm{C}(3)=\mathrm{C}(4)$ & $\mathrm{O}(2) \mathrm{N}(2) \mathrm{O}(3)$ & $121.7(3)$ \\
& $\mathrm{N}(2)-\mathrm{O}(1)$ & $1.383(2)$ & $\mathrm{O}(3) \mathrm{N}(2) \mathrm{O}(1)$ & $118.1(2)$ \\
& $\mathrm{N}(2)-\mathrm{O}(2)$ & $1.229(3)$ & $\mathrm{O}(6) \mathrm{N}(3) \mathrm{O}(5)$ & $122.4(3)$ \\
& $\mathrm{N}(2)-\mathrm{O}(3)$ & $1.249(4)$ & $\mathrm{O}(5) \mathrm{N}(3) \mathrm{O}(4)$ & $117.8(3)$ \\
\hline
\end{tabular}

\footnotetext{
${ }^{\text {a }}$ Symmetry code: (i) $-x+1,-y,-z+1$.

${ }^{\mathrm{b}} m$ is the midpoint of the $\mathrm{C}(3)=\mathrm{C}(4)$ bond.
}

Table 5 Geometry of selected H-contacts in the structures of I and II.

\begin{tabular}{|c|c|c|c|c|c|c|}
\hline \multirow[t]{2}{*}{ № } & \multirow[t]{2}{*}{ Contact $D-\mathrm{H} . . . A$} & \multicolumn{3}{|c|}{ Bond length, $\AA$} & \multirow{2}{*}{$\begin{array}{c}\text { Angle } D-\mathrm{H} . . . A \text {, } \\
\text { deg }\end{array}$} & \multirow[t]{2}{*}{ Atom coordinates of $A$} \\
\hline & & $D-\mathrm{H}$ & Н...A & $D \ldots A$ & & \\
\hline \multirow[t]{7}{*}{ I } & $\mathrm{C}(1)-\mathrm{H}(11) \ldots \mathrm{O}(3)$ & 0.97 & 2.48 & $3.320(3)$ & 144 & $1.5-x,-0.5+y, z$ \\
\hline & $\mathrm{C}(1)-\mathrm{H}(12) \ldots \mathrm{O}(4)$ & 0.97 & 2.57 & $3.330(3)$ & 135 & $x, y, z$ \\
\hline & $\mathrm{C}(4)-\mathrm{H}(42) \ldots \mathrm{O}(4)$ & 0.93 & 2.68 & $3.539(4)$ & 154 & $0.5-x,-0.5+y, z$ \\
\hline & $\mathrm{C}(5)-\mathrm{H}(51) \ldots \mathrm{O}(4)$ & 0.96 & 2.65 & $3.429(4)$ & 139 & $1-x,-0.5+y, 1.5-z$ \\
\hline & $\mathrm{C}(5)-\mathrm{H}(52) \ldots \mathrm{O}(2)$ & 0.96 & 2.63 & $3.383(3)$ & 136 & $-0.5+x, y, 1.5-z$ \\
\hline & $\mathrm{C}(6)-\mathrm{H}(63) \ldots \mathrm{O}(3)$ & 0.96 & 2.68 & $3.580(3)$ & 156 & $1-x,-y, 1-z$ \\
\hline & $\mathrm{C}(6)-\mathrm{H}(62) \ldots \mathrm{O}(3)$ & 0.96 & 2.70 & $3.471(4)$ & 138 & $1.5-x,-0.5+y, z$ \\
\hline \multirow[t]{9}{*}{ II } & $\mathrm{C}(1)-\mathrm{H}(11) \ldots \mathrm{O}(6)$ & 0.97 & 2.44 & $3.308(4)$ & 149 & $-x,-0.5+y, 2.5-z$ \\
\hline & $\mathrm{C}(1)-\mathrm{H}(12) \ldots \mathrm{O}(2)$ & 0.97 & 2.50 & $3.405(4)$ & 156 & $-1+x,-0.5-y,-0.5+z$ \\
\hline & $\mathrm{C}(2)-\mathrm{H}(21) \ldots \mathrm{O}(5)$ & 0.97 & 2.45 & $3.380(4)$ & 161 & $1-x,-0.5+y, 2.5-z$ \\
\hline & $\mathrm{C}(2)-\mathrm{H}(22) \ldots \mathrm{O}(5)$ & 0.97 & 2.72 & $3.530(5)$ & 142 & $x, 0.5-y,-0.5+z$ \\
\hline & $\mathrm{C}(2)-\mathrm{H}(22) \ldots \mathrm{O}(3)$ & 0.97 & 2.44 & $3.211(4)$ & 136 & $1-x, 0.5+y, 2.5-z$ \\
\hline & $\mathrm{C}(3)-\mathrm{H}(31) \ldots \mathrm{O}(1)$ & 0.93 & 2.53 & $3.440(4)$ & 165 & $1-x,-0.5+y, 2.5-z$ \\
\hline & $\mathrm{C}(4)-\mathrm{H}(41) \ldots \mathrm{O}(2)$ & 0.93 & 2.61 & $3.425(5)$ & 147 & $1-x, 0.5+y, 2.5-z$ \\
\hline & $\mathrm{C}(4)-\mathrm{H}(42) \ldots \mathrm{O}(2)$ & 0.93 & 2.62 & $3.340(5)$ & 135 & $-1+x, y, z$ \\
\hline & $\mathrm{C}(5)-\mathrm{H}(53) \ldots \mathrm{O}(2)$ & 0.96 & 2.63 & $3.481(4)$ & 149 & $-1+x,-0.5-y,-0.5+z$ \\
\hline
\end{tabular}

\section{References}

[1] R. Pen, M. Li, D. Li, Coord. Chem. Rev. 254(1-2) (2010) 1-18.

[2] M.M. Monchak, A.V. Pavlyuk, V.V. Kinzhibalo, M.G. Mys'kiv, Russ. J. Coord. Chem. 35(6) (2009) 405-410.

[3] M.M. Monchak, A.V. Pavlyuk, V.V. Kinzhibalo, V.V. Glukhyy, M.G. Mys'kiv, Russ. J. Coord. Chem. 36(3) (2010) 198-203.
[4] M.M. Monchak, E.A. Goreshnik, M.G. Mys'kiv, Russ. J. Coord. Chem. 37(2) (2011) 143-148.

[5] M.M. Monchak, E.A. Goreshnik, M.G. Mys'kiv, Russ. J. Struct. Chem. 53(1) (2012) 119-124.

[6] K. Weygand, G. Hilgetag, Organisch-Chemische Experimentierkunst, Barth, Leipzig, 1964.

[7] B.M. Mykhalichko, M.G. Mys'kiv, Ukr. Patent No. 25450A, Bull. No. 6, 1998.

[8] CrystalClear, Rigaku Corporation, The Woodlands, Texas, 1999. 
M. Monchak et al., Synthesis and crystal structure of N,N'-diallyl-N,N,N',N'-tetramethylethylenediammonium ...

[9] R.C. Clark, J.S. Reid, Acta Crystallogr. A 51(6) (1995) 887-897.

[10] A. Altomare, G. Cascarano, C. Giacovazzo, A. Guagliardi, M.C. Burla, G. Polidori, M. Camalli, J. Appl. Crystallogr. 27(3) (1994) 435.

[11] G.M. Sheldrick, SHELXS-97 and SHELXL-97, Programs for the Solution and Refinement of Crystal Structures, University of Göttingen, Germany, 1997.

[12] DIAMOND v3.1, Crystal Impact GbR, Bonn, Germany, 2004-2005.

[13] V.V. Olijnyk, M.G. Mys'kiv, Z. Anorg. Allg. Chem. 621(10) (1995) 1741-1745.
[14] V. Olijnyk, T. Glowiak, M. Mys'kiv, J. Chem. Crystallogr. 25(10) (1995) 621-624.

[15] V.V. Olijnyk, E.A. Goreshnik, M.G. Mys'kiv, V.K. Pecharsky, Russ. J. Struct. Chem. 35(1) (1994) 87-90.

[16] Ya.E. Filinchuk, V.V. Olijnik, V.N. Davydov, Koord. Khim. 23(11) (1997) 843-845.

[17] Ya.E. Filinchuk, M.G. Mys'kiv, Pol. J. Chem. 74(7) (2000) 927-933.

[18] K. Biradha, Cryst. Eng. Comm. 5 (2003) 374-384. 